\title{
Rekayasa Proses Bisnis Layanan Pengiriman Paket
}

\author{
http://dx.doi.org/10.28932/jutisi.v7i2.3485 \\ Riwayat Artikel \\ Received: 02 Maret 2021 | Final Revision: 22 Juli 2021 | Accepted: 01 Agustus 2021 \\ Tiur Gantini ${ }^{\bowtie \# 1}$, Yasinta Kurnia Wijaya ${ }^{\# 2}$ \\ \# Program studi SI Sistem Informasi, Universitas Kristen Maranatha \\ Jalan Surya Sumantri No. 65, Kota Bandung, Jawa Barat 40164 \\ 1tiur.gantinieit.maranatha.edu \\ 21773003@maranatha.ac.id
}

\begin{abstract}
During the pandemic, companies engaged in package delivery did not experience a negative impact, instead they experienced rapid development and new companies emerged. This study discusses business process engineering related to package delivery services in courier companies. Data research was collected through an interview method with one of the staff working in Jalur Nugraha Ekakurir (JNE) company Setrasari Bandung and a direct observation method related to this service. From the data research, it is known that the business processes 'AS-IS' are then carried out in business process engineering. It is recommended that agents and branches be able to sort packages so that if the package is in the nearest area it can be sent directly to the intended address according to the type of package chosen by the customer, with costs that include insurance for damage and loss of goods. And the courier on duty has been confirmed to be well trained, passed the test and knows the conditions of the location in the area very well.
\end{abstract}

Keywords - BPR; business process reengineering; services.

\section{PENDAhUluan}

Di era pandemik yang telah terjadi di Indonesia sejak tahun 2020 berdampak terhadap semua aspek kehidupan masyarakat Indonesia. Demikian juga berdampak terhadap bisnis-bisnis yang ada baik yang menghasilkan produk maupun jasa. Setiap perusahaan berusaha untuk bertahan di dalam situasi pandemic ini, karena tidak ada kepastian yang jelas apa yang akan terjadi ke depan terhadap perusahaan tersebut.

PT JNE merupakan perusahaan yang bergerak di bidang jasa kurir yang telah lama berdiri di Indonesia [1]. Sejak terjadinya pandemic ternyata untuk perusahaan yang bergerak di bidang jasa kurir tidak mengalami pengaruh yang terlalu signifikan [2][3], justru berkembang pesat di Indonesia sehingga banyak perusahaan kurir baru bermunculan sebagai kompetitor dari perusahaan JNE ini, karena di saat pandemi kegiatan pembelanjaan elektronik naik sebesar 69\% [4].

Dengan bermunculannya banyak kompetitor di bidang jasa kurir sejenis, maka JNE merasa perlu untuk menjaga kualitas layanan dan kepuasan konsumen sehingga konsumen tetap loyal terhadap layananan JNE. Oleh karena itu perlu dilakukan analisis proses bisnis terhadap layanan yang ada saat ini di JNE, sehingga dapat direkomendasikan sebuah proses bisnis sebagai hasil dari rekayasa proses bisnis yang ada saat ini. Di dalam penelitian kali ini studi kasus diambil Dari JNE yang ada di kota Bandung.

\section{Metode Penelitian}

Metodologi penelitian dari "Rekayasa Proses Bisnis Layanan Pengiriman Paket" dapat dilihat pada Gambar 1 yang terdiri dari wawancara dan observasi (pengamatan) terhadap tempat yang dijadikan studi kasus yaitu PT JNE Setrasari Bandung, studi literatur, analisis proses bisnis, rekayasa proses bisnis dan diakhiri dengan kesimpulan. Setiap tahapan dalam metode penelitian akan dibahas pada bagian ini.

\section{A. Wawancara dan Observasi Studi Kasus}

Wawancara dilaksanakan dengan salah satu staf JNE cabang Setrasari Bandung serta observasi langsung terhadap layanan kurir JNE yang dilaksanakan selama bulan Agustus 2020. Pelaksanaan wawancara serta observasi berfokus terhadap layanan jasa pengiriman paket di JNE Kota Bandung. 


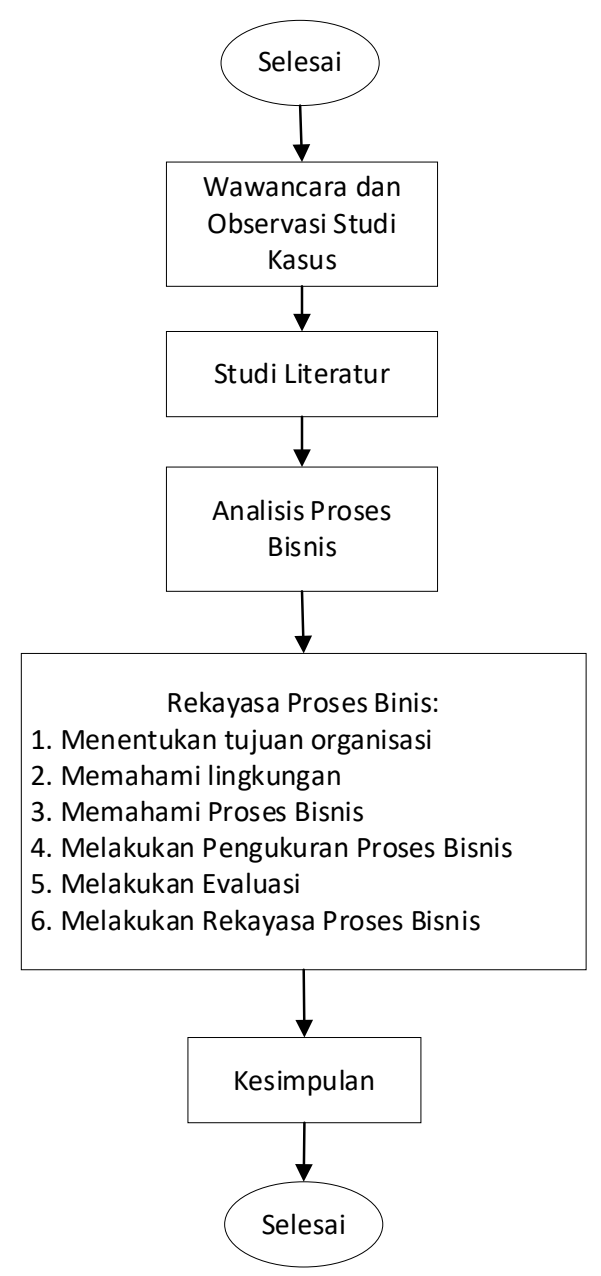

Gambar 1. Metodologi Rancangan Instrumen Kepuasan Layanan Pelanggan berdasarkan Proses Bisnis

\section{B. Studi Literatur}

Studi literatur "Rekayasa Proses Bisnis Layanan Pengiriman Paket" akan membahas terkait proses bisnis, rekayasa proses bisnis, metode rekayasa proses bisnis dan penelitian yang terkait dengan topik penelitian tersebut.

1. Rekayasa Proses Bisnis

Rekayasa proses bisnis merupakan pemikiran kembali dan perancangan proses bisnis sebuah organisasi dari proses bisnis yang ada saat ini. Tujuan rekayasa proses bisnis adalah untuk membuat proses lebih efisien dan memberikan kepuasan kepada pengguna layanan [5][6][7].

2. Penelitian Terkait

Penelitian dalam Tabel 1 membahas beberapa penelitian yang terkait dengan topik penelitian rekayasa proses bisnis untuk layanan pengiriman paket.

TABEL 1

PENELITIAN TERKAIT

\begin{tabular}{|c|c|c|c|}
\hline Peneliti & Judul Penelitian & Hasil Penelitian & $\begin{array}{c}\text { Urgensi } \\
\text { Penelitian }\end{array}$ \\
\hline $\begin{array}{c}\text { Tiamaz dkk } \\
{[8]}\end{array}$ & $\begin{array}{l}\text { "A Business Process } \\
\text { Improvement Method" }\end{array}$ & $\begin{array}{l}\text { Penelitian ini mengusulkan metode Lean untuk perbaikan } \\
\text { proses bisnis dan implementasi metode Lean dengan studi } \\
\text { kasus di rumah sakit Moulay Ismail di Meknes, Maroko. } \\
\text { Makalah ini menganalisis } 34 \text { metode Lean dari domain yang } \\
\text { berbeda untuk mengidentifikasi langkah-langkah yang harus }\end{array}$ & \begin{tabular}{lr}
\multicolumn{3}{l}{ Menggunakan } \\
metode & studi \\
literatur $\quad$ terkait \\
dengan metode \\
Lean utk rekayasa
\end{tabular} \\
\hline
\end{tabular}




\begin{tabular}{|c|c|c|c|}
\hline Peneliti & Judul Penelitian & Hasil Penelitian & $\begin{array}{c}\text { Urgensi } \\
\text { Penelitian }\end{array}$ \\
\hline & & $\begin{array}{l}\text { diikuti, alat yang digunakan serta prinsip-prinsip untuk } \\
\text { memeriksa keberhasilan implementasi Lean. }\end{array}$ & proses bisnis \\
\hline $\begin{array}{l}\text { Oktavianty dkk } \\
\text { [9] }\end{array}$ & $\begin{array}{l}\text { "Business Process } \\
\text { Reengineering Approach for } \\
\text { Quality Reporting Process } \\
\text { (Case Study at PT } \\
\text { Domusindo Perdana)" }\end{array}$ & $\begin{array}{l}\text { Proses evaluasi rekayasa proses bisnis pelaporan kualitas di } \\
\text { Departemen Quality Assurance (QA) terbukti efektif untuk } \\
\text { meningkatkan efisiensi kerja. Hal ini meningkatkan efisiensi } \\
\text { kerja dari } 58,02 \% \text { menjadi } 76 \% \text {. Jumlah langkah dari total } \\
\text { proses berkurang dari } 27 \text { menjadi } 12 \text { langkah sebagai proses } \\
\text { modifikasi dari tipe seri ke tipe paralel dan menghilangkan } \\
\text { beberapa langkah. Sistem online dengan penerapan teknologi } \\
\text { informasi pada sistem dilakukan untuk menggantikan sistem } \\
\text { offline dan memberikan peningkatan radikal dalam } \\
\text { mempersingkat total waktu proses pelaporan kualitas dan } \\
\text { mengurangi biaya dengan sistem pengisian tanpa kertas. } \\
\text { Penerapan business process re-engineering juga dapat } \\
\text { diterapkan pada proses lain di perusahaan. }\end{array}$ & $\begin{array}{l}\text { Menerapkan } \\
\text { rekayasa proses } \\
\text { bisnis }\end{array}$ \\
\hline $\begin{array}{l}\text { Tambunan dkk } \\
\text { [10] }\end{array}$ & $\begin{array}{l}\text { "Penerapan Lean } \\
\text { Manufacturing } \\
\text { menggunakan Value Stream } \\
\text { Mapping (VSM) untuk } \\
\text { Identifikasi Waste \& } \\
\text { Performance Improvement } \\
\text { Pada UKM Shoes and Care" }\end{array}$ & $\begin{array}{l}\text { Penelitian dilakukan pada studi kasus Shoes and Care, } \\
\text { khususnya pada pelayanan fast clean, produktivitas studi kasus } \\
\text { masih dapat dioptimalkan menggunakan konsep Lean } \\
\text { Manufacturing. Dengan menggunakan penggambaran aliran } \\
\text { proses kerja menggunakan VSM, disimpulkan terdapat } \\
\text { pemborosan pada proses pendaftaran manual, penuangan cairan } \\
\text { ke wadah, pencarian dan pembersihan alat. Kemudian } \\
\text { dilakukan perbaikan terhadap proses-proses tersebut. Setelah } \\
\text { dilakukan perbaikan maka waktu pelayanan fast clean menjadi } \\
\text { diharapkan menjadi lebih ringkas dan kualitas pelayanan yang } \\
\text { lebih baik. }\end{array}$ & $\begin{array}{l}\text { Sama-sama } \\
\text { menggunakan } \\
\text { VSM }\end{array}$ \\
\hline $\begin{array}{l}\text { Rayasa dkk } \\
\text { [11] }\end{array}$ & $\begin{array}{l}\text { Strategi Komunikasi } \\
\text { Customer Service PT. JNE } \\
\text { Cabang Utama Samarinda } \\
\text { dalam menangani kasus } \\
\text { keluhan pelanggan }\end{array}$ & $\begin{array}{l}\text { Melakukan analisis semua keluhan pelanggan terkait kasus JNE } \\
\text { di Cabang Utama Samarinda sehingga diusulkan sebuah } \\
\text { strategi yang lebih baik untuk dapat menangani keluhan } \\
\text { pelanggan. }\end{array}$ & $\begin{array}{l}\text { Menganalisis } \\
\text { keluhan pelanggan } \\
\text { terhadap layanan } \\
\text { pengiriman paket } \\
\text { di PT JNE namun } \\
\text { di Cabang Utama } \\
\text { Samarinda }\end{array}$ \\
\hline $\begin{array}{l}\text { Anugrah dkk } \\
\text { [12] }\end{array}$ & $\begin{array}{l}\text { Usulan Pengurangan Waste } \\
\text { Proses Produksi } \\
\text { Menggunakan Waste } \\
\text { Asessment Model dan Value } \\
\text { Steam Mapping DI PT. X }\end{array}$ & $\begin{array}{l}\text { Melakukan penelitian untuk mengurangi waste pada proses } \\
\text { produksi di PT X dan mengusulkan hasil rekayasa proses bisnis } \\
\text { dengan penggunaan model waste asessment model dan value } \\
\text { steam mapping. }\end{array}$ & $\begin{array}{l}\text { Menggunakan } \\
\text { SVM juga namun } \\
\text { ada tambahan } \\
\text { yaitu } \\
\text { menggunakan } \\
\text { waste asessment } \\
\text { model yang tidak } \\
\text { digunakan dalam } \\
\text { penelitian ini }\end{array}$ \\
\hline Badiru dkk [13] & $\begin{array}{l}\text { Quantification of the PICK } \\
\text { chart for process } \\
\text { improvement decisions }\end{array}$ & $\begin{array}{l}\text { Menggunakan teknik kuantitatif dengan menerapkan pick chart } \\
\text { untuk meningkatkan pengambilan keputusan dan proses } \\
\text { operasional dan selanjutnya dilakukan transformasi proses } \\
\text { bisnis dalam organisasi militer dan pemerintahan. }\end{array}$ & $\begin{array}{l}\text { Menggunakan } \\
\text { Pick Chart di } \\
\text { dalam membuat } \\
\text { rekayasa proses } \\
\text { bisnis }\end{array}$ \\
\hline
\end{tabular}

\section{Analisis Proses Bisnis}

Dari hasil pada tahap A dan B, maka dilakukan analisis proses bisnis terhadap layanan kurir PT JNE. Hasil analisis Proses Bisnis dituangkan di dalam bentuk narasi kemudian dimodelkan dengan menggunakan notasi standar proses bisnis yaitu notasi. Hasil Analisis Proses Bisnis dapat dilihat pada Hasil Penelitian bagian B.

\section{Rekayasa Proses Bisnis}

Rekayasa Proses Bisnis dibuat berdasarkan hasil analisis proses bisnis dengan melakukan tahap sebagai berikut:

1. Menentukan tujuan organisasi : diperoleh dari visi dan misi organisasi

2. Memahami lingkungan organisasi : melakukan pengamatan dan memilih proses 
3. Memahami proses yang ada saat ini dengan melakukan pemetaan proses bisnis. Pemetaan proses bisnis diterapkan dengan menggunakan metode Value Steam Mapping (VSM). VSM merupakan alur proses khusus yang menggunakan simbol bahasa metode Lean untuk menggambarkan dan meningkatkan efisiensi alur informasi perusahaan. Tujuan VSM adalah memberi nilai optimal bagi konsumen dengan meminimumkan biaya [14].

4. Melakukan pengukuran proses dengan menggunakan metode sebagai berikut:

a. Voice of Customer (VOC) disebut juga suara pelanggan diperoleh dengan metode wawancara secara acak kepada 10 (sepuluh) orang pengguna jasa pengiriman paket JNE dan pengamatan secara langsung serta melalui studi literatur.

b. Voice of Business (VOB) disebut juga suara perusahaan diperoleh dengan metode wawancara dengan staf JNE dan pengamatan secara langsung.

5. Melakukan evaluasi dengan menggunakan metode pick chart [15]. Pick Chart adalah alat Six Sigma yang dapat dipakai untuk mengkategorikan gagasan-gagasan untuk perbaikan proses. Tujuan matriks ini adalah untuk membantu mengidentifikasi gagasan-gagasan yang paling memberikan manfaat. Matriks berbentuk kotak berbentuk 2 x 2 , pada umumnya digambarkan pada papan tulis atau kertas besar. Gagasan-gagasan ditulis dan ditempel pada kotak berdasarkan hasil dan tingkat kesulitan[16] [17]. Setiap kotak diberi istilah yang berasal dari label untuk masing-masing kuadran yang terdiri dari label sebagai berikut:

a. Implement or Just Do It merupakan gagasan yang ideal atau mudah untuk dilakukan dengan memberikan dampak hasil yang sangat baik baik bagi perusahaan maupun pelanggan;

b. Possible (tepat) merupakan gagasan yang mudah untuk dilakukan namun memberikan dampak hasil yang rendah;

c. Challenge (tantangan) merupakan hal yang sulit dilakukan dengan memberikan dampak hasil yang rendah; dan

d. Kill (memusnahkan) merupakan gagasan yang sulit sekali untuk dilakukan dengan memberikan dampak hasil yang rendah.

6. Melakukan rekayasa proses bisnis adalah proses rekayasa proses bisnis (Business Process Reengineering) yang dilakukan berdasarkan tahapan kelima. Rekayasa Proses bisnis digambarkan dengan menggunakan notasi standar proses bisnis. Cara termudah untuk mengikuti aturan format halaman paper ini adalah menggunakan format dalam dokumen ini. Simpanlah file ini dengan nama lainnya, lalu ketikkan isi makalah anda ke dalamnya.

\section{HASIL DAN PEMBAHASAN}

Hasil Penelitian akan membahas mengenai proses bisnis yang ada saat ini

\section{A. Proses Bisnis Saat Ini}

Proses Bisnis adalah sekumpulan kegiatan terstruktur dan saling terkait yang dikerjakan oleh manusia atau alat atau fungsi bisnis dimana tahapan kegiatan tersebut menghasilkan produk atau jasa bagi pelanggannya guna mencapai tujuan bisnis tertentu [6][18]. Hasil dari tahap wawancara dan observasi, maka diperoleh profil perusahaan JNE yang berpusat di Jakarta dan memiliki banyak cabang di kota-kota di Indonesia, antara lain di kota Bandung, Solo, Yogyakarta, Semarang, Surabaya, Balikpapan, Palembang, Medan, dan kota lainnya. JNE mempunyai beberapa layanan yang dibagi menjadi 3 bagian yaitu: JNE Express, JNE Logistik, dan JNE Freight. Layanan di JNE logistik yaitu : angkutan darat, angkutan laut, dan pergudangan. Sedangkan JNE freight terdapat layanan Jaringan JNE Freight, Jasa Kepabeanan, Air Freight, Ocean Freight. Terdapat 17 (tujuh belas) produk dan layanan dari JNE Express[1].

Pada kesempatan kali ini hanya dibahas terkait layanan JNE untuk pengiriman paket saja. Dan proses bisnis terkait layanan JNE dapat dilihat pada Gambar 2 yang digambarkan dengan model standar proses bisnis. Proses bisnis menjelaskan layanan JNE secara umum yang digambarkan dari hasil wawancara dengan staf JNE Setrasari Bandung serta pengamatan langsung. Proses dimulai dari konsumen yang akan mengirimkan paket melalui bantuan jasa kurir JNE, secara rinci dijelaskan pada tahapan berikut:

1) Konsumen tersebut akan memberikan paket itu pada JNE Agen terdekat.

2) JNE Agen akan menampung barang dan mengumpulkan paket lainnya, karena JNE Agen merupakan tempat sementara untuk menampung berbagai paket.

3) Jika paket sudah terkumpul maka JNE Agen akan mengirimkannya ke JNE Cabang. JNE Cabang biasanya lebih besar daripada JNE Agen dimana JNE Cabang merupakan tempat terakhir dari pendistribusian barang dari berbagai tempat JNE Agen.

4) JNE Cabang menerima paket yang dikirim oleh JNE Agen, untuk kemudian semua paket tersebut diperiksa dan dipilah-pilah terlebih dahulu berdasarkan alamat penerima dan layanan yang digunakan.

5) Setelah tahapan ke 4) JNE Cabang di kota Bandung akan dikirimkan terlebih dahulu ke JNE Jakarta (warehouse).

6) Di warehouse tersebut akan dilakukan pengecekan ulang untuk pemilahan sesuai dengan alamat tujuan dan layanan yang digunakan lalu mulai didistribusikan ke cabang masing-masing.

7) Setelah selesainya pendistribusian dan barang telah sampai pada JNE Cabang kota tujuan, maka akan dilakukan pembagian berdasarkan lokasi (apakah lokasi tujuan dekat dengan JNE cabang atau tidak), jika dekat maka akan dikirimkan 
langsung oleh kurir JNE, tetapi tidak dirasa alamat tujuan jauh dari JNE Cabang maka paket akan dikirimkan ke JNE agen yang terdekat yang sesuai dengan alamat tujuan.

8) Sesampainya paket di JNE Agen, maka paket akan dikirimkan oleh kurir JNE ke alamat penerima.

\section{B. Rekayasa Proses Bisnis}

Dalam tahapan rekayasa proses bisnis digunakan tahapan yang telah dibahas pada bagian II.A, dan diimplementasikan sebagai berikut:

1. Menentukan tujuan organisasi JNE yang diperoleh dari visi, misi dan nilai-nilai perusahaan sebagai berikut [1]:

- Visi : JNE akan menjadi perusahaan rantai pasok global terdepan di dunia

- $\quad$ Misi

: JNE akan memberi pengalaman terbaik kepada pelanggan secara konsisten

- Nilai-nilai $\quad$ JNE memiliki nilai-nilai jujur, disiplin, tanggung jawab, dan visioner.

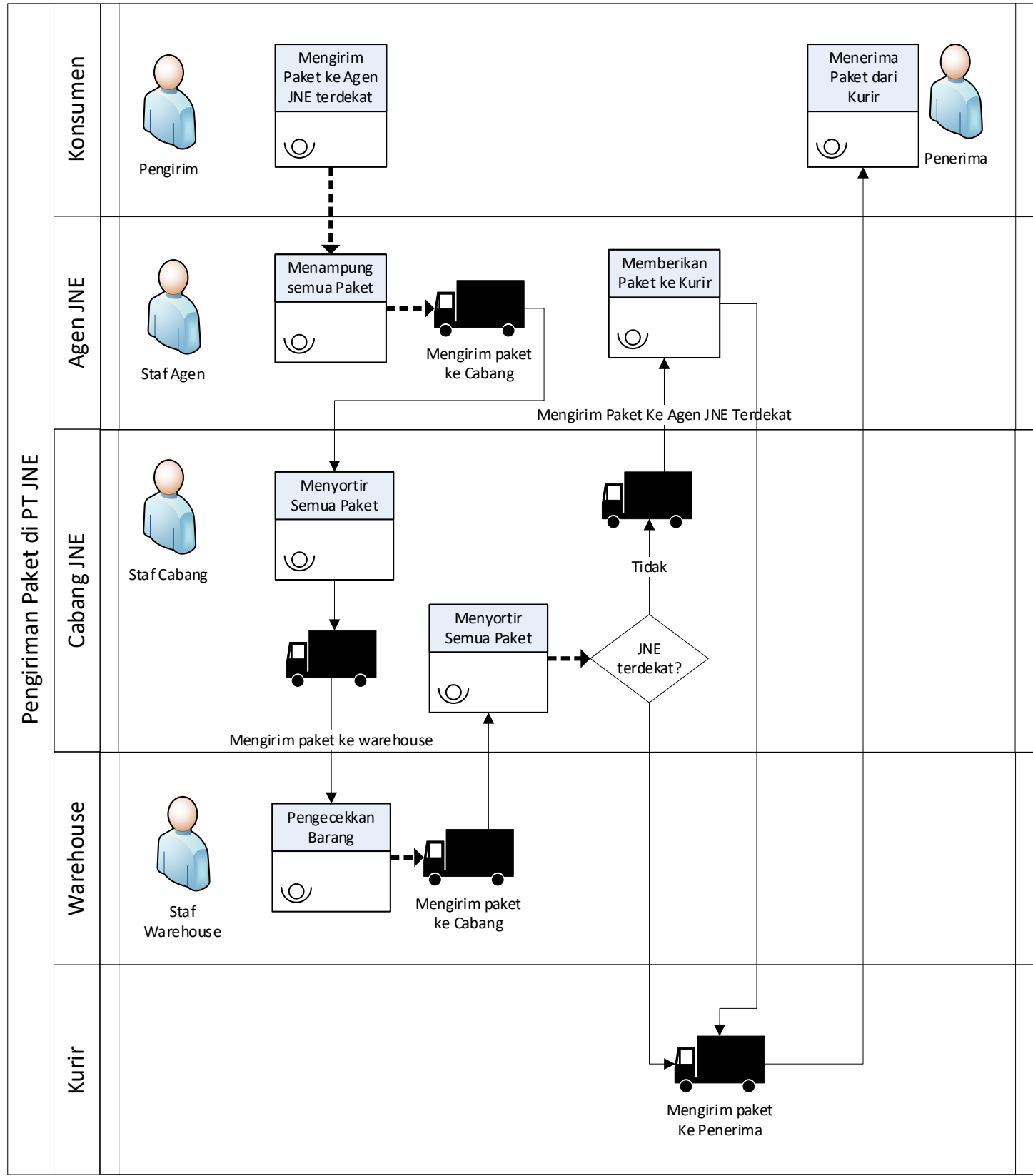

Gambar 2. Proses Bisnis Layanan JNE 
2. Memahami lingkungan organisasi: melakukan pengamatan dan memilih proses.

Pengamatan dilakukan pada bulan Agustus 2020 dan proses yang dipilih adalah proses terkait layanan pengiriman paket yang telah dijabarkan pada bagian II.A.

3. Memahami proses: memetakan proses yang ada saat ini kemudian melakukan pengukuran dengan menerapkan metode VSM.

Metode VSM digunakan untuk menganalisis masalah serta solusi yang muncul dalam setiap langkah proses. Pada Gambar 3 terlihat bahwa metode VSM menggunakan beberapa warna yang memiliki makna berbeda. Warna biru mengidentifikasi dokumen awal dan akhir proses, warna hijau mengidentifikasikan setiap proses, warna jingga mengidentifikasi setiap masalah yang terjadi pada setiap langkah proses, dan warna kuning mengidentifikasi setiap solusi yang dikerjakan di dalam sistem yang diberikan untuk setiap masalah. Selain warna yang berbeda, dalam metode VSM pun mencatat waktu yang diperlukan saat melakukan proses tersebut yang digambarkan dengan menggunakan panah dan waktu yang diperlukan untuk setiap waktu.

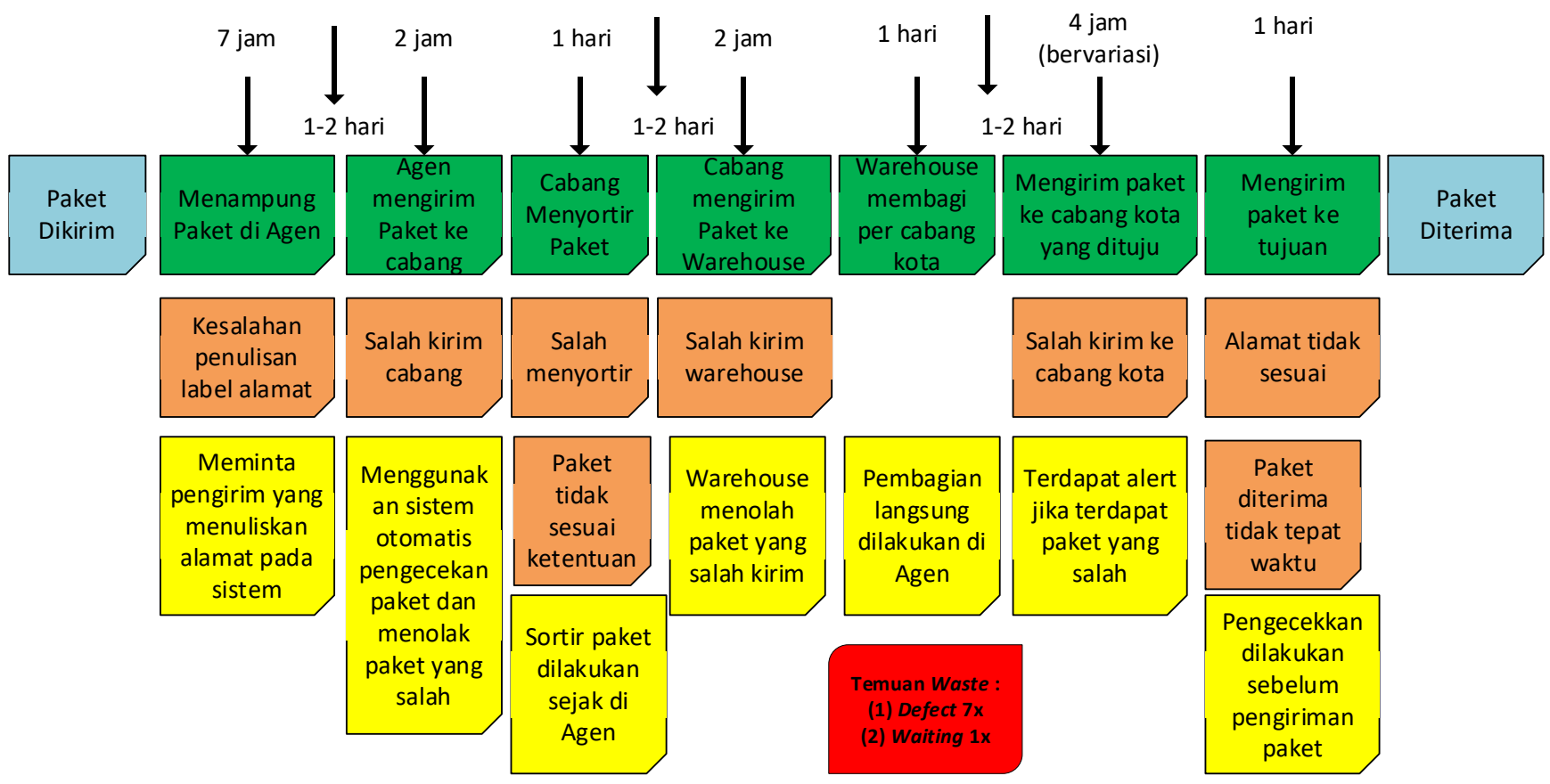

Gambar 3. Pemetaan Proses Bisnis dengan metode VSM

Dengan memetakan proses bisnis menggunakan metode VSM diperoleh 8 (delapan) waste dalam proses layanan pengiriman paket pada Gambar 3 yang berwarna jingga. Dalam kedelapan waste yang terjadi, terbagi menjadi (2) dua kategori yaitu defects yang berarti masalah terjadi karena kesalahan dan waiting yang berarti masalah terjadi karena waktu untuk menunggu suatu proses. Kategori defect terdiri dari 7 (tujuh) kali dan kategori waiting sebanyak 1 (satu) kali. Dari waste yang terjadi selanjutnya akan dicari solusi untuk mengatasi hal tersebut dengan kotak yang berwarna kuning.

1. Melakukan pengukuran proses dengan menerapkan metode Voice of Customer (VOC) dan Voice of Business (VOB) a. Voice of Customer (VOC) yang disebutkan dengan suara pelanggan dari hasil wawancara dan pengamatan dapat dilihat pada Tabel 2.

Tabel 2 menunjukkan terdapat beberapa kesalahan yang diterima oleh pelanggan saat pengiriman paket. Dengan menggunakan metode VOC, dapat dilakukan analisis untuk mengetahui penyebab utama terjadinya masalah yang ada. Setelah diketahui penyebab utama masalah tersebut, maka dapat ditemukan solusi agar pelanggan tidak mengalami masalah tersebut. Contohnya seperti masalah yang dialami oleh pelanggan yaitu paket tidak diterima sesuai waktu yang dijanjikan, untuk jenis pengiriman YES (Yakin Esok Hari Sampai) 1 (satu) hari, Regular bergantung pada alamat yang terletak di kota yang dituju. Penyebab masalah ini dapat terjadi pada sistem, manusia (staf) ataupun alat transportasi yang digunakan oleh perusahaan. Solusi dari masalah ini adalah perbaikan sistem, 
melatih staf, menempatkan staf dengan kompetensi yang tepat serta terdapat alat transportasi cadangan yang dapat menggantikan alat transportasi yang mengalami kendala.

TABEL 2

SUARA PELANGGAN

\begin{tabular}{|c|c|c|}
\hline Suara Pelanggan & Isu Utama & Hal yang Kritis bagi Pelanggan \\
\hline $\begin{array}{l}\text { "Paket tidak diterima sesuai waktu } \\
\text { yang dijanjikan" [11][19][20][21] }\end{array}$ & $\begin{array}{l}\text { Proses pengiriman } \\
\text { diterima pelanggan }\end{array}$ & $\begin{array}{l}\text { Paket tiba sesuai atau lebih cepat } \\
\text { dari waktu yang dijanjikan }\end{array}$ \\
\hline $\begin{array}{l}\text { "Paket diterima dalam keadaan rusak" } \\
{[22][23][24]}\end{array}$ & Paket rusak & Kerusakan tidak diganti \\
\hline $\begin{array}{l}\text { "Paket tiba di alamat yang salah" } \\
{[25][26][27]}\end{array}$ & Salah alamat pe & Paket tidak diterima \\
\hline
\end{tabular}

b. Voice of The Business (VOB) disebut dengan suara hati perusahaan yang diperoleh melalui wawancara dengan staf terkait. VOB dapat dilihat pada Tabel 3.

TABEL 3

SUARA PERUSAHAAN

\begin{tabular}{lll}
\hline \multicolumn{1}{c}{ Suara hati perusahaan } & \multicolumn{1}{c}{ Isu Utama } & Hal yang Kritis bagi Perusahaan \\
\hline $\begin{array}{l}\text { "Paket yang dikirim tidak sesuai } \\
\text { aturan" }\end{array}$ & Paket Ilegal & $\begin{array}{l}\text { Paket Ilegal bisa mengakibatkan } \\
\text { pelanggaran hukum }\end{array}$ \\
\hline $\begin{array}{l}\text { "Pelanggan tidak mau } \\
\text { mengasuransikan paketnya" }\end{array}$ & Paket tidak berasuransi & $\begin{array}{l}\text { Pelanggan menuntut kehilangan } \\
\text { paket tidak berasuransi ke } \\
\text { perusahaan }\end{array}$ \\
$\begin{array}{l}\text { "Pelanggan tidak memberikan alamat } \\
\text { tujuan yang lengkap" }\end{array}$ & Paket tidak sampai tujuan & $\begin{array}{l}\text { Biaya yang dikeluarkan untuk paket } \\
\text { yang salah tujuan }\end{array}$ \\
\hline
\end{tabular}

Tabel 3 mengukur jumlah masalah yang terjadi di dalam perusahaan. Dari masalah yang diperoleh pada tabel 3, selanjutnya akan dianalisis apa yang menjadi penyebab alasan masalah tersebut terjadi. Analisis dilakukan untuk menentukan hasil yang dikehendaki proses pengiriman paket. Contoh analisis yang telah dilakukan menggunakan VOB adalah didapatkannya suatu masalah yang dialami oleh pihak perusahaan yaitu paket yang dikirim tidak sesuai dengan aturan perusahaan, misalnya mengirimkan paket berisi cairan tanpa menggunakan paket standar dengan kayu. Setelah dilakukan analisis, penyebab terjadinya masalah tersebut adalah tidak ada sistem yang dapat melihat isi paket dan ketidakjujuran dari pelanggan dalam mengirimkan barang. Selanjutnya perlu dicari solusi yang tepat, yaitu mempunyai sebuah alat yang dapat melihat dalam paket tanpa harus membongkarnya dan membuat perjanjian jika paket tidak sesuai dengan aturan perusahaan, maka paket dapat dihancurkan oleh perusahaan atau melaporkan kepada pihak berwenang sebagai pelanggaran dari pelanggan.

2. Melakukan evaluasi proses bisnis dengan menggunakan metode pick chart. Berdasarkan Tabel 2 dan 3 dicatat solusi yang direkomendasikan yang dapat dilihat pada Tabel 4.

TABEL 4

REKOMENDASI SOLUSI VOC DAN VOB

\begin{tabular}{ll}
\hline \multicolumn{1}{c}{ Suara hati pelanggan atau perusahaan } & \multicolumn{1}{c}{ Solusi yang direkomendasikan } \\
\hline $\begin{array}{l}\text { "Paket tidak diterima sesuai waktu yang dijanjikan" } \\
{[11][19][20][21]}\end{array}$ & $\begin{array}{l}\text { Mengurangi atau menghilangkan waste yang ada dalam } \\
\text { proses bisnis saat ini }\end{array}$ \\
\hline "Paket diterima dalam keadaan rusak" $[22][23][24]$ & $\begin{array}{l}\text { Biaya asuransi kerusakan dan kehilangan dimasukkan } \\
\text { secara langsung ke dalam biaya paket }\end{array}$ \\
\hline "Paket tiba di alamat yang salah" $[25][26][27]$ & $\begin{array}{l}\text { Melatih, menguji dan menyiapkan kurir dengan sangat } \\
\text { baik sebelum bertugas di lapangan }\end{array}$ \\
\hline "Paket yang dikirim tidak sesuai aturan" & Mengembalikan paket kepada pengirim \\
\hline "Pelanggan tidak mau mengasuransikan paketnya" & $\begin{array}{l}\text { Biaya asuransi kerusakan dan kehilangan dimasukkan } \\
\text { secara langsung ke dalam biaya paket }\end{array}$ \\
\hline "Pelanggan tidak memberikan alamat tujuan yang & $\begin{array}{l}\text { Memiliki alat otomatis untuk pengecekkan alamat yang } \\
\text { dituju }\end{array}$ \\
\hline lengkap" &
\end{tabular}


Gambar pick chart dapat dilihat pada Gambar 4, yang terdiri dari 4 (empat) kuadran berikut:

a. Implement or Just Do It (Dapat dilakukan) merupakan gagasan yang ideal atau mudah untuk dilakukan dengan memberikan dampak hasil yang sangat baik baik bagi perusahaan maupun pelanggan;

b. Possible (Tepat) merupakan gagasan yang mudah untuk dilakukan dengan memberikan hasil yang rendah;

c. Challenge (Tantangan) merupakan hal yang sulit dilakukan dengan memberikan dampak hasil yang tinggi; dan

d. Kill (memusnahkan) merupakan gagasan yang sulit sekali untuk dilakukan dengan memberikan dampak hasil yang rendah.

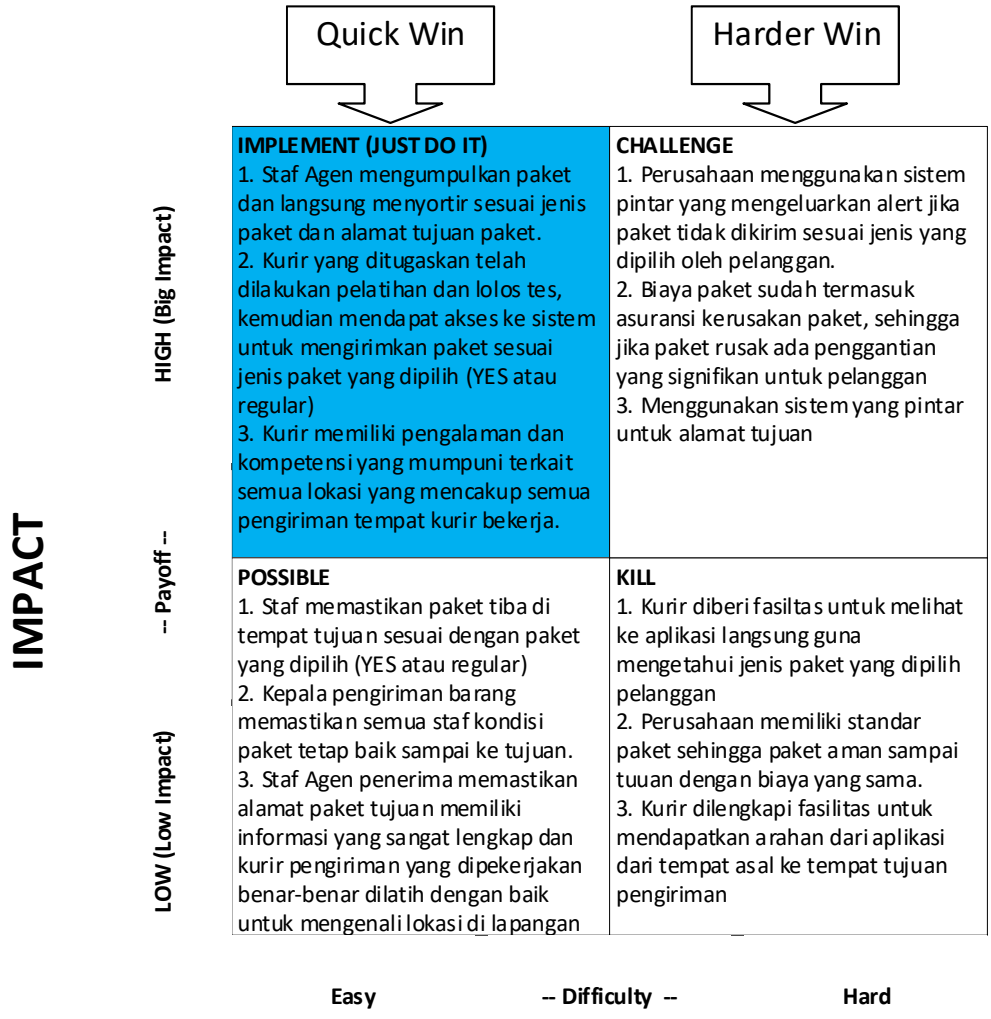

\section{EASE OF IMPLEMENTATION}

Gambar 4. Pick Chart untuk Mencari Akar Masalah pada Layanan Pengiriman Paket

Pick Chart adalah metode yang digunakan dalam analisis proses pengiriman paket. Metode ini membantu dalam menjabarkan solusi dan gagasan untuk rekayasa proses bisnis sehingga menjadi lebih efektif. Setiap solusi atau gagasan yang didapatkan akan dimasukkan ke dalam kategori yang berbeda sesuai dengan besar atau kecilnya dampak yang akan dialami dan mudah atau sulitnya pelaksanaan dari solusi gagasan tersebut tersebut [16] [17]. Ada empat kategori dalam Pick Chart [15] ini yang disertai dengan hasil dari ide atau solusi yang didapatkan, yaitu:

a. Implement atau Just do it (Berdampak tinggi, mudah diimplementasikan):

1) Staf Agen mengumpulkan paket dan langsung menyortir sesuai jenis paket dan alamat tujuan paket.

2) Kurir yang ditugaskan telah dilakukan pelatihan dan lolos tes, kemudian mendapat akses ke sistem untuk mengirimkan paket sesuai jenis paket yang dipilih (YES atau regular)

3) Kurir memiliki pengalaman dan kompetensi yang mumpuni terkait semua lokasi yang mencakup semua pengiriman tempat kurir bekerja.

b. Possible (Berdampak rendah, mudah diimplementasikan):

1) Staf memastikan paket tiba di tempat tujuan sesuai dengan paket yang dipilih (YES atau regular).

2) Kepala pengiriman barang memastikan semua staf kondisi paket tetap baik sampai ke tujuan. 
3) Staf agen penerima memastikan alamat paket tujuan memiliki informasi yang sangat lengkap dan kurir pengiriman yang dipekerjakan benar-benar dilatih dengan baik untuk mengenali lokasi di lapangan dengan sangat baik.

c. Challenge (Berdampak tinggi, sulit diimplementasikan):

1) Perusahaan menggunakan sistem pintar yang mengeluarkan alert jika paket tidak dikirim sesuai jenis yang dipilih oleh pelanggan.

2) Biaya paket sudah termasuk asuransi kerusakan paket, sehingga jika paket rusak ada penggantian yang signifikan untuk pelanggan

3) Menggunakan sistem yang pintar untuk alamat tujuan

d. Kill (Berdampak kecil, sulit diimplementasikan) :

1) Kurir diberi fasilitas untuk melihat ke aplikasi langsung guna mengetahui jenis paket yang dipilih pelanggan dan Agen diberikan kesempatan untuk langsung dikirim ke tujuan tidak harus dikirim ke cabang, kemudian ke warehouse dan dikirimkan ke alamat tujuan.

2) Perusahaan memiliki standar paket sehingga paket aman sampai tujuan dengan biaya yang sama.

3) Kurir dilengkapi fasilitas untuk mendapatkan arahan dari aplikasi dari tempat asal ke tempat tujuan pengiriman

3. Melakukan rekayasa proses bisnis dengan mengambil dari pick chart pada kuadran Implement or Just Do It yang berwarna biru pada Gambar 4. Tabel 5 membandingkan tahapan dari proses bisnis yang ada saat ini dengan hasil rekayasa proses bisnis yang dilakukan.

TABEL 5

Perbandingan Proses Bisnis SaAt Ini dan Hasil ReKayasa Proses Bisnis

\begin{tabular}{l}
\hline Proses Bisnis Saat Ini \\
\hline 1. Konsumen akan memberikan paket itu pada JNE Agen \\
terdekat. \\
2. JNE Agen akan menampung barang dan mengumpulkan \\
paket lainnya, karena JNE Agen merupakan tempat \\
sementara untuk menampung berbagai paket. \\
3. Jika paket sudah terkumpul maka JNE Agen akan \\
mengirimkannya ke JNE Cabang. JNE Cabang biasanya \\
lebih besar daripada JNE Agen dimana JNE Cabang \\
merupakan tempat terakhir dari pendistribusian barang dari \\
berbagai tempat JNE Agen.
\end{tabular}

4. JNE Cabang menerima paket yang dikirim oleh JNE Agen, untuk kemudian semua paket tersebut diperiksa dan dipilahpilah terlebih dahulu berdasarkan alamat penerima dan layanan yang digunakan.

5. Setelah tahapan ke 4) JNE Cabang di kota Bandung akan dikirimkan terlebih dahulu ke JNE Jakarta (Warehouse).

6. Di warehouse tersebut akan dilakukan pengecekan ulang untuk pemilahan sesuai dengan alamat tujuan dan layanan yang digunakan lalu mulai didistribusikan ke cabang masing-masing.

7. Setelah selesainya pendistribusian dan barang telah sampai pada JNE Cabang kota tujuan, maka akan dilakukan pembagian berdasarkan lokasi (apakah lokasi tujuan dekat dengan JNE cabang atau tidak), jika dekat maka akan dikirimkan langsung oleh kurir JNE, tetapi tidak dirasa alamat tujuan jauh dari JNE Cabang maka paket akan dikirimkan ke JNE agen yang terdekat yang sesuai dengan alamat tujuan.

8. Sesampainya paket di JNE Agen, maka paket akan dikirimkan oleh kurir JNE ke alamat penerima.

\section{Rekayasa Proses Bisnis}

1. Konsumen tersebut akan memberikan paket itu pada JNE Agen terdekat.

2. Staf Agen mengumpulkan paket dan langsung menyortir sesuai jenis paket YES (Yakin Esok Hari Sampai) atau regular dan alamat tujuan paket, memastikan kemasan paket aman sesuai dengan isi paketnya. Jika alamat tujuan dekat dengan posisi Agen JNE, maka Agen menginformasikan kepada kurir yang bertugas untuk mengirimkan. Biaya pengiriman sudah termasuk biaya asuransi kerusakan dan kehilangan barang.

3. Kurir yang ditugaskan telah dilakukan pelatihan dan lolos tes, kemudian mendapat akses ke sistem untuk mengirimkan paket sesuai jenis paket yang dipilih (YES atau regular) dan memiliki pengalaman serta kompetensi yang mumpuni terkait semua lokasi yang mencakup semua pengiriman tempat kurir bekerja.

4. Kurir mengirimkan paket ke alamat tujuan sesuai dengan jenis paket.

Dari Tabel 5 dapat dilihat bahwa peran Agen dan Cabang diusulkan untuk menjadi sama yaitu dapat menyortir, sehingga paket dapat diberikan kepada kurir untuk segera dikirimkan ke alamat tujuan. Sehingga waktu untuk pengiriman lebih 
singkat dengan harapan paket dapat diterima sesuai dengan jenis paket yang dipilih. Biaya pengiriman paket sudah termasuk dengan asuransi kerusakan barang dan kehilangan barang. Dan kurir yang bertugas adalah kurir yang telah melalui masa pelatihan yang memadai sehingga kurir memiliki kompetensi baik terhadap lokasi pengiriman di lapangan dan bagaimana menggunakan sistem informasi yang ada untuk mendukung pengiriman paket tiba di lokasi yang tepat. Penggambaran akhir untuk rekomendasi rekayasa proses bisnis pengiriman paket dapat dilihat dalam Gambar 5.

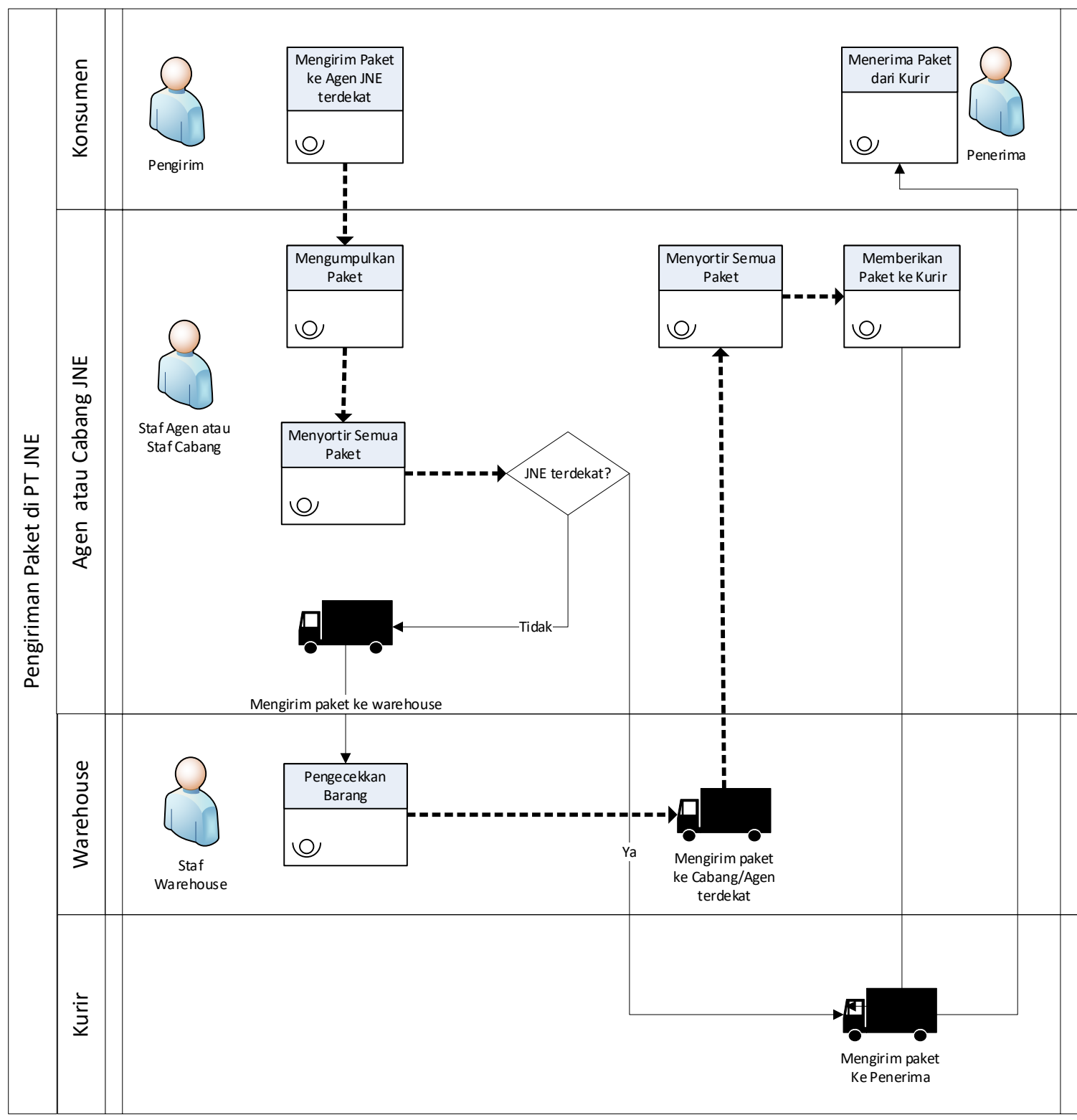

Gambar 5. Rekomendasi Rekayasa Proses Bisnis Pengiriman Paket

\section{SIMPULAN}

Penelitian ini menghasilkan rekayasa proses bisnis mengenai layanan pengiriman paket dengan studi kasus di JNE Kota Bandung. Hasil penelitian memberikan rekomendasi proses bisnis yang menggabungkan peran Agen dan Cabang sehingga proses sortir bisa lebih cepat dan dapat segera dikirimkan oleh kurir PT JNE sehingga paket dapat tiba dan diterima sesuai dengan jenis paket yang dipilih. Biaya paket diusulkan sudah diatur termasuk biaya kerusakan dan biaya kehilangan. Dan kurir yang bertugas di lapangan sudah dijamin telah dilatih, diuji dan disiapkan dengan sangat baik dalam mengirimkan paket ke lokasi yang sesuai dengan yang dituju. 


\section{UCAPAN TERIMA KASIH}

Ucapan terimakasih disampaikan kepada pihak perusahaan JNE Bandung Cabang Setrasari yang telah bersedia diwawancarai sehingga diperoleh data yang valid untuk penelitian ini.

\section{DAFTAR PUSTAKA}

[1] JNE, "Profil Perusahaan JNE," Profil Perusahaan JNE, 2019. https://www.jne.co.id/id/perusahaan/profil-perusahaan (accessed Jul. 01, 2021).

[2] T. Zafira, "Dampak Baik Pandemi Covid-19 Jasa Pengiriman Kurir,” 2021. https://kumparan.com/tsana-zafira/dampak-baik-pandemi-covid-19jasa-pengiriman-kurir-1ut87stSt8Q/full (accessed Jul. 01, 2021).

[3] K. Safitri, "Belanja Online Meningkat, Sektor Logistik Panen Untung," Jakarta, Sep. 28, 2020.

[4] R. R. Behera, M. Gutgutia, A. Jayaprakasan, D. Shrivastava, and M. Khanna, "Report On Indonesia ECommerce | Metamorphosis In A Post Covid World," Bengaluru, May 01, 2020.

[5] M. Weske, Business process management: Concepts, languages, architectures, second edition. 2012.

[6] M. Kirchmer, High performance through business process management: Strategy execution in a digital world, third edition, 3rd ed. West Chester: Springer, 2017.

[7] H. Leopold, Business Process Management, vol. 168. 2013.

[8] Y. Tiamaz, F. Lahboube, and N. Souissi, “A business process improvement method,” Proc. Int. Conf. Ind. Eng. Oper. Manag., vol. 2018, no. SEP, pp. 823-836, 2018.

[9] O. Oktavianty, "Bussiness Process Reengingeering Approach for Quality Reporting Process (Case Study at PT D. Perdana, Pasuruan)," J. Eng. Manag. Ind. Syst., vol. 6, no. 1, pp. 1-10, 2018, doi: 10.21776/ub.jemis.2018.006.01.1.

[10] R. A. Tambunan et al., "Penerapan Lean Manufacturing menggunakan Value Stream Mapping (VSM) untuk Identifikasi Waste \& Performance Improvement Pada UKM 'Shoes and Care," Ind. Eng. Online J., vol. 6, no. 4, pp. 1-6, 2017.

[11] R. F. Rayasa, S. Rande, and K. D. Dwivayani, "Strategi Komunikasi Customer Service Pt . Jne Cabang Utama Samarinda Dalam Menangani Kasus Keluhan Pelanggan,” eJuournal Ilmu Komun., vol. 7, no. 2, pp. 233-242, 2019.

[12] M. Anugrah and R. Zaini, Emsosfi, "Usulan Pengurangan Waste Proses Produksi Menggunakan Waste Asessment Model Dan Value Stream Mapping Di Pt . X,” J. Online Inst. Teknol. Nas., vol. 4, no. 01, pp. 110-120, 2016.

[13] A. B. Badiru and M. U. Thomas, "Quantification of the PICK chart for process improvement decisions," J. Enterp. Transform., vol. 3, no. 1, pp. 1-15, 2013, doi: 10.1080/19488289.2013.784221.

[14] J. Bicheno and M. Holweg, The Lean Toolbox, 5th edition. A handbook for lean transformation. Lean Books View project Special Issue: The Digitalization of Manufacturing View project, 5th ed., no. January. Buckingham, England: PICSIE, 2016.

[15] M. L. George, Lean Six Sigma for services. Seoul, Korea: McGrawHill, 2006.

[16] J. W. Wittwer, "PICK Chart for Lean Six Sigma," vertex42.com, 2017. https://www.vertex42.com/ExcelTemplates/PICK-chart.html (accessed Jul. 01, 2021).

[17] Suwandi, "PICK Chart," sixsigmaindonesia.com, 2020. http://sixsigmaindonesia.com/pick-chart/ (accessed Jul. 01, 2021).

[18] M. Weske, Business Process Management Concepts, Languages, Architectures, 2nd ed. Potsdam, Germany: Springer, Berlin, Heidelberg, 2012.

[19] PHT, "JNE Pusat Tolak Komplain Konsumen," harianjayapos.com, Jakarta, 2020.

[20] E. Catriana, "Layanan mendapat keluhan masyarakat, manajemen JNE beri penjelasan," kontan.co.id, Jakarta, 2020.

[21] Ina, "Keluhan Terhadap Ekspedisi JNE," mediakonsumen.com, 2020. https://mediakonsumen.com/2020/06/15/surat-pembaca/keluhan-terhadapekspedisi-jne\#comment-55056 (accessed Jul. 01, 2021).

[22] Herniwati, "Keluhan Terhadap Ekspedisi JNE," mediakonsumen.com, 2020. https://mediakonsumen.com/2020/06/15/surat-pembaca/keluhanterhadap-ekspedisi-jne (accessed Jul. 01, 2021).

[23] Prasetyo, "Keluhan Terhadap Ekspedisi JNE," mediakonsumen.com, 2020. https://mediakonsumen.com/2020/06/15/surat-pembaca/keluhanterhadap-ekspedisi-jne\#comment-55046 (accessed Jul. 01, 2021).

[24] Abdul, "Keluhan Terhadap Ekspedisi JNE," mediakonsumen.com, 2020. https://mediakonsumen.com/2020/06/15/surat-pembaca/keluhanterhadap-ekspedisi-jne\#comment-55029 (accessed Jul. 01, 2021).

[25] Tony, "Keluhan Terhadap Ekspedisi JNE," mediakonsumen.com, 2021. https://mediakonsumen.com/2020/06/15/surat-pembaca/keluhanterhadap-ekspedisi-jne\#comment-79390 (accessed Jul. 01, 2021).

[26] Epi, "Keluhan Terhadap Ekspedisi JNE," 2020. https://mediakonsumen.com/2020/06/15/surat-pembaca/keluhan-terhadap-ekspedisijne\#comment-55043 (accessed Jul. 01, 2021).

[27] Soetrina, "Keluhan Terhadap Ekspedisi JNE," mediakonsumen.com, 2020. https://mediakonsumen.com/2020/06/15/surat-pembaca/keluhanterhadap-ekspedisi-jne\#comment-55073 (accessed Jul. 01, 2021). 